\title{
Novos táxons e notas sobre Cerambycinae (Coleoptera, Cerambycidae) da Região Neotropical
}

\author{
Ubirajara R. Martins ${ }^{1,3}$ \& Maria Helena M. Galileo ${ }^{2,3}$ \\ ${ }^{1}$ Museu de Zoologia, Universidade de São Paulo. Caixa Postal 42494, 04218-970 São Paulo, São Paulo, Brasil. \\ 2 Museu de Ciências Naturais, Fundação Zoobotânica do Rio Grande do Sul. Caixa Postal 1188, 90001-970 Porto Alegre, \\ Rio Grande do Sul, Brasil. \\ ${ }^{3}$ Bolsista do CNPq.
}

\begin{abstract}
New taxa and notes on Neotropical Cerambycinae (Coleoptera, Cerambycidae). New taxa described in Oemini: Paramartinsia gen. nov., type species, P. quadrimaculata sp. nov. and Sepaicutea costata sp. nov. both from Bolivia; in Ectenessini: Ectenesseca gen. nov., type species, E. clavula sp. nov. from Brazil (Rondônia); in Piezocerini: Haruspex insulsus sp. nov. from Panama; in Eburiini: Pantomallus rugosus sp. nov.; Eburodacrys apua sp. nov., E. xirica sp. nov. all from Bolívia; in Oxycoleini: Oxycoleus cyaneus sp. nov. from Bolivia. New records: Bomarion achrostum Napp \& Martins, 1982; Pantomallus proletarius (Erichson, 1847). A key to the species of Pantomallus is added.

KEY WORDS. Eburiini, Ectenessini, Oemini, Oxycoleini, Piezocerini.
\end{abstract}

RESUMO. São descritos novos táxons em Oemini: Paramartinsia gen. nov., espécie-tipo, P. quadrimaculata sp. nov. e Sepaicutea costata sp. nov. ambas da Bolívia; em Ectenessini: Ectenesseca gen. nov., espécie-tipo, E. clavula sp. nov. do Brasil (Rondônia); em Piezocerini: Haruspex insulsus sp. nov. do Panamá; em Eburiini: Pantomallus rugosus sp. nov.; Eburodacrys apua sp. nov., E. xirica sp. nov., todas da Bolívia; em Oxycoleini: Oxycoleus cyaneus sp. nov. da Bolívia. Novos registros: Bomarion achrostum Napp \& Martins, 1982 e Pantomallus proletarius (Erichson, 1847). Acrescenta-se chave para as espécies de Pantomallus.

PALAVRAS CHAVE. Eburiini, Ectenessini, Oemini, Oxycoleini, Piezocerini.

Com base em material enviado para estudo por J. Wappes (American Coleoptera Museum, Bulverde, ACMB), apresentamos novos registros e descrições de novos táxons. Grande parte do material é procedente da Bolívia e, por determinação de Wappes, os holótipos das espécies bolivianas devem ser depositados no "Museo de Historia Natural Noel Kempf Mercado", Santa Cruz (MNKM) e os das espécies procedentes de outros países no "National Museum of Natural History", Washington (USNM), Coleção Roy Morris, Lakeland, Florida (CRML), Coleção Gino Nearnse (CGN) no "Florida State Collection of Arthropods", Gainesville (FSCA). Parte do material foi retido para o Museu de Ciências Naturais, Fundação Zoobotânica do Rio Grande do Sul, Porto Alegre (MCNZ) e para o Museu de Zoologia, Universidade de São Paulo, São Paulo (MZSP). As dimensões são fornecidas em milímetros.

\section{Oemini}

\section{Paramartinsia gen. nov.}

Etimologia. Latim, para = perto; Martinsia, nome de gênero de Oemini.

Fronte transversal. Palpos maxilares pouco mais longos que os labiais; último artículo dos palpos labiais subcilíndrico. Tubérculos anteníferos pouco projetados e distantes. Olhos grosseiramente facetados e não divididos. Distância entre os lobos oculares superiores maior do que a largura de um lobo. Antenas (fêmea) ultrapassam as extremidades elitrais no ápice do antenômero VIII. Escapo com algumas asperezas, sem cicatriz e mais curto do que o antenômero III. Antenômero III aproximadamente um terço mais longo do que o IV; franja interna de pêlos (fêmea) curtos e densos. Protórax mais largo que longo, bem constrito na base; lados com espinho longo atrás do meio. Pronoto com duas pequenas gibosidades ântero-laterais; base sem lobo. Mesonoto sem sulco. Processo prosternal laminiforme, apenas ultrapassa as procoxas. Processo mesosternal laminiforme, não ultrapassa as mesocoxas. Élitros com manchas tegumentares ebúrneas; costa apenas indicada; extremidades subaguçadas com espículo apical. Metafêmures sublineares, apenas engrossados no terço apical. Metatarsômero I curto, subigual ao II+III.

Discussão. Pela chave para os gêneros de Oemina (MarTins 1997b: 18), Paramartinsia gen. nov. é discriminado no item 10 por apresentar: processos esternais laminiformes e lados do protórax com espinho. Nesse item separam-se os gêneros 
Temnopis Audinet-Serville, 1834; Gounelloeme Monné \& Martins, 1974; Martinsia Chemsak \& Linsley, 1957 e Sepaicutea Lane, 1972.

Os olhos em Paramartinsia gen. nov. são inteiros e o metatarsômero I é apenas mais longo do que II+III, caracteres que o distinguem de Temnopis. A fronte é nitidamente mais larga do que longa, os tubérculos anteníferos são muito distantes entre si e o escapo é reto, peculiaridades que o distinguem de Gounelloeme.

Paramartinsia assemelha-se mais a Martinsia, mas distingue-se: pelas antenas das fêmeas mais longas que o corpo e providas de pêlos abundantes no lado interno dos flagelômeros basais; pela presença de somente duas gibosidades apenas projetadas no pronoto; pelo mesonoto sem sulco; pelos élitros com manchas tegumentares ebúrneas e extremidades acuminadas.

\section{Paramartinsia quadrimaculata sp. nov.}

\section{Fig. 1}

Etimologia. Latim, quadrimaculata = quatro manchas; alusivo às manchas ebúrneas dos élitros.

Tegumento predominante alaranjado. Cada élitro com duas manchas ebúrneas subelípticas: uma na base, entre o úmero e o escutelo, e uma no meio. Extremo apical do escapo preto em pequena extensão. Protórax com manchas pretas, duas látero-anteriores no pronoto; duas de cada lado das partes laterais: uma circular, á frente do meio e uma imediatamente acima das procoxas. Manchas pretas nos élitros: região posterior da mancha basal (pode faltar); adiante e atrás das manchas centrais e duas pequenas manchas oblíquas anteapicais. Extremidades dos meso- e metafêmures e tarsos também pretos, exceto o tarsômero V. Áreas pretas na face ventral: pequena mancha na extremidade posterior dos metepisternos e, às vezes, no meio e nos lados dos urosternitos.

Cabeça com pontos rasos. Pronoto (50 x) com grânulos. Élitros fina e densamente pontuados, menos sobre as manchas que são lisas. Costa elitral apenas indicada.

Dimensões, fêmea. Comprimento total, 14,4-18,0; comprimento do protórax, 2,0-2,7; maior largura do protórax, 2,63,7; comprimento do élitro, 10,2-13,3; largura umeral, 3,2-4,2.

Material-tipo. Holótipo fêmea, Bolívia, Santa Cruz: Buena Vista (Hotel Flora \& Fauna), 22-26.X.2002, Morris \& Wappes leg. (MNKM). Parátipos: ditto, (Hotel Flora \& Fauna, 3,7 km SSE, 430 m), fêmea, 5-15.XI.2001, M. C. Thomas \& B. K. Dozier leg., "black light trap, tropical transition forest" (MZSP); ditto, fêmea, 18-25.X.1992, E. Giesbert leg. (ACMB).

\section{Sepaicutea costata sp. nov.}

Fig. 2

Etimologia. Latim, costatus $=$ com costelas; alusivo às costas elitrais.

Colorido geral castanho; urosternitos mais escuros. Cabeça com pêlos muito curtos e esparsos. Vértice fina e densa- mente pontuado, os pontos rasos e microesculturados internamente (40 x). Olhos com pêlos curtos e raros entre os omatídios. Lobos oculares superiores largos, tão distantes entre si quanto a largura de um lobo. Tubérculos anteníferos gradualmente projetados. Antenas atingem o ápice dos élitros na ponta do antenômero IX. Escapo gradualmente engrossado para o ápice com cerca da metade do comprimento do antenômero III (fêmea). Protórax com projeção lateral no nível do terço basal. Pronoto $(50 \mathrm{x})$ microesculturado sem elevações; fina e esparsamente pubescente; partes laterais com pêlos mais longos e curvos. Élitros com duas costas lisas, largas e bem evidentes.

Dimensões, fêmea. Comprimento total, 11,1; comprimento do protórax, 1,4; maior largura do protórax,1,7; comprimento do élitro, 8,7; largura umeral, 2,1.

Material-tipo. Holótipo fêmea, Bolívia, Santa Cruz: Achira (4-5 km N, Rodovia para Amboro), 21-22.X.2000, Morris \& Wappes leg. (MNKM).

Discussão. Sepaicutea costata sp. nov. assemelha-se à $S$. unicolor Martins, 1997 pelo colorido castanho uniforme. Difere pela presença de costas bem marcadas nos élitros e pelas antenas das fêmeas mais longas que o corpo. Sepaicutea unicolor não apresenta costas nos élitros e as antenas das fêmeas atingem a extremidade elitral a partir do ápice do antenômero VII.

\section{Ectenessini}

\section{Bomarion achrostum Napp \& Martins, 1982}

Bomarion achrostum Napp \& Martins, 1982: 378; Martins, 1998: 167.

Espécie até o momento conhecida do holótipo procedente do Peru, Junin: Tingo Maria. Ampliamos a distribuição para a Bolívia.

Material examinado. Bolívia, Santa Cruz: Buenavista (Hotel Flora \& Fauna, 3,7 km SSE, $430 \mathrm{~m}$ ), macho, 15-22.XI.2001, B. K. Dozier leg., "black light trap, transition forest" (MZSP); ditto (4 km SSE), 15-22.X.2001, Dozier \& Thomas leg. (ACMB).

\section{Ectenesseca gen. nov.}

Espécie-tipo, Ectenesseca clavula sp. nov.

Etimologia. Combinação do gênero-tipo Ectenessa com a palavra latina secus = diferente.

Fronte mais larga que longa. Lobos oculares superiores com quatro fileiras de omatídios; tão afastados entre si quanto o sêxtuplo da largura de um lobo. Genas com o ápice arredondado. Palpos maxilares com o dobro do comprimento dos palpos labiais. Tubérculos anteníferos projetados e distantes entre si. Antenas com onze artículos; atingem o ápice dos élitros na ponta do antenômero VIII (fêmea). Escapo gradualmente engrossado para o ápice sem pontos ásperos. Antenômero III sem sulco no lado dorsal; um terço mais longo do que o IV. Protórax mais longo do que largo; lados com gibosidade acentuada, central; mais constrito anteriormente do que na base. Pronoto microgranulado $(50 \mathrm{x})$, convexo e sem tubérculos. 
Metade anterior do prosterno com finas rugas transversais. Processo prosternal não ultrapassa as coxas anteriores, com um quarto da largura de uma procoxa. Prosterno sem tubérculo. Processo mesosternal com lados paralelos, tão largo quanto dois terços de uma mesocoxa, com expansões articulares laterais bem projetadas e inciso no ápice. Élitros sem pubescência fina; com pêlos longos esparsos; extremidades arredondadas. Epipleuras sem dilatação. Fêmures pedunculados e acentuadamente clavados. Profêmures sem quilha dorsal. Metatíbias sem sulco. Metatarsômero I com o dobro do comprimento do II e III em conjunto.

Discussão. Assemelha-se a Lissoeme Martins, Chemsak \& Linsley, 1966, mas difere pelo escapo sem pontos ásperos; protórax com gibosidade lateral acentuada; processo mesosternal com superfícies articulares laterais e extremidade entalhada; tegumento dos élitros sem microescultura; ápice dos élitros arredondado. Em Lissoeme, escapo com pontuação rugosa, protórax ligeiramente arredondado lateralmente, processo mesosternal sem superfícies articulares laterais e com a extremidade entalhada, élitros microesculturados com os ápices obliquamente truncados e armadura variável.

De Ectenessidia Gounelle, 1909, diferencia-se pela distância entre os lobos oculares superiores com o sêxtuplo da largura de um lobo; escapo liso e sem asperezas; protórax com grande gibosidade lateral; pronoto convexo; processo mesosternal com superfícies articulares laterais longas; fêmures fortemente pedunculados e clavados; metatarsômero I com o dobro do comprimento de II mais III. Em Ectenessidia os lobos oculares superiores estão separados entre si pelo triplo da largura de um lobo; escapo com asperezas discretas ou densamente pontuado; lados do protórax sem gibosidade; pronoto plano; processo mesosternal sem superfícies articulares; fêmures pouco e gradualmente engrossados para o ápice; metatarsômero I com um terço do comprimento de II mais III.

\section{Ectenesseca clavula sp. nov.}

Fig. 3

Etimologia. Latim, clavula, diminutivo de clava; alusivo à forma dos fêmures.

Colorido geral alaranjado. Escapo, pedicelo e flagelômeros basais pretos; flagelômeros apicais alaranjados. Fêmures pretos no pedúnculo e no ápice; avermelhados na clava. Tíbias pretas. Tarsômeros I e II pretos; III a V alaranjados. Cabeça microesculturada e muito esparsamente pubescente. Escapo e pedicelo brilhantes; flagelômeros finamente pubescentes. Élitros pontuados, mais esparsamente para os ápices. Face ventral finamente pubescente.

Dimensões, fêmea. Comprimento total, 10,1; comprimento do protórax, 2,0; maior largura do protórax, 1,8; comprimento do élitro, 7,5; largura umeral, 2,2.

Material-tipo. Holótipo fêmea, BrAsIL, Rondônia: Ariquemes (62 km SW, Fazenda Rancho Grande), 16.XI.1994, C. O’Brien leg., armadilha de luz ultravioleta (ACMB).

Revista Brasileira de Zoologia 22 (3): 764-770, setembro 2005

\section{Piezocerini \\ Haruspex insulsus sp. nov.}

Fig. 4

Etimologia. Latim, insulsus = insípido.

Colorido geral amarelo-sujo. Tegumento acastanhado: área atrás dos lobos oculares inferiores; faixa centro-longitudinal no pronoto; duas faixas longitudinais, uma a cada lado, da constrição basal ao meio; partes laterais do protórax, prosterno, mesosterno, mesepimeros, mesepisternos, grande parte do metasterno e área no meio das clavas femorais. Nos élitros, tegumento acastanhado numa faixa longitudinal da base ao terço anterior; faixa em forma de "V" (ramo externo metade do comprimento do interno) no meio; friso sutural no terço apical; mancha alongada sob os úmeros. Tubérculos pronotais pouco acentuados. Costa elitral manifesta; extremidades com espinho curto no lado externo.

Dimensões, fêmea. Comprimento total, 6,4; comprimento do protórax, 1,2; maior largura do protórax, 1,1; comprimento do élitro, 4,8; largura umeral, 1,5.

Material-tipo. Holótipo fêmea, Panamá, Panamá: Rodo-

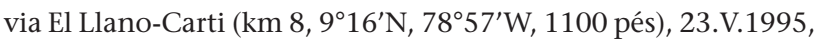
B. Ratcliffe \& M. Jameson leg. (USNM).

Discussão. Haruspex insulsus sp. nov. pertence ao grupo I (Martins 1976) que reúne H. modestus (White, 1855) e H. pictilis Martins, 1976. Difere de ambas pela distribuição do colorido castanho em todo o corpo, principalmente, faixa longitudinal no centro do pronoto e as faixas elitrais.

\section{Eburiini}

Acreditamos ter examinado o primeiro exemplar de Pantomallus proletarius (Erichson, 1847) após a menção do lectótipo (Gilmour 1966). Torna-se então necessário publicar nova chave para espécies de Pantomallus sul-americanas que atualiza aquela publicada por Martins (1999: 202), inclui espécie nova da Bolívia e espécies publicadas recentemente: $P$. martinezi Martins \& Galileo, 2002 e P. titinga Galileo \& Martins, 2004.

\section{Chave para as espécies sul-americanas de Pantomallus}

1. Élitros com aspecto opaco, com pubescência densa ou muito densa, manchas ou faixas ebúrneas dos élitros contíguas, com distância entre faixas menor que largura de uma faixa; sem faixas leitosas, estreitas, atrás das manchas ebúrneas

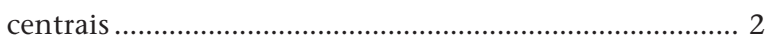

1'. Élitros com aspecto brilhante com pubescência muito esparsa; faixas ebúrneas dos élitros separadas entre si por distância igual à largura de uma faixa; com faixas leitosas atrás das manchas ebúrneas centrais. Brasil (Rondônia, Mato Grosso, São Paulo) ..................... P. reclusus (Martins, 1981)

2. Pontuação da metade anterior dos élitros finíssima, uniforme, restrita à microescultura e praticamente sem pontos maiores entremeados; (colorido geral castanho ou castanho-avermelhado; ápices dos meso- e metafêmures desar- 
mados). Brasil (Paraíba ao Rio Grande do Sul, Goiás), Paraguai, Argentina, Uruguai .....

P. morosus (A.-Serville, 1834)

2'. Pontuação da metade anterior dos élitros constituída por pontos maiores bem visíveis sob a pilosidade 3

3. Comprimento dos élitros cerca de seis vezes o comprimento do protórax; colorido geral acastanhado; (manchas elitrais diminutas; abas apicais dos meso- e metafêmures não aguçadas). Fig. 5. Peru, Bolívia (Santa Cruz)

P. proletarius (Erichson, 1847)

3'. Comprimento dos élitros aproximadamente cinco vezes (ou menos) o comprimento do protórax; manchas elitrais, principalmente as centrais externas, alongadas

4. Élitros com pontos ásperos principalmente na base e ao longo da sutura $(40 \mathrm{x})$; colorido geral castanho. Fig. 6. Bolívia P. rugosus sp. nov.

4'. Élitros com pontuação simples; colorido geral avermelhado ou amarelado

5. Costas elitrais bem visíveis e aparentes atrás das manchas ebúrneas centrais; (ápices dos meso- e metafêmures com espinho no lado interno)

5'. Costas elitrais não aparentes atrás das manchas centrais 7

6. Mesofêmures (machos) largos, achatados e curvos na base; colorido geral mais amarelado. Brasil (Bahia, Minas Gerais a Santa Catarina) P. pallidus Aurivillius, 1923

6'. Mesofêmures (machos) estreitos, sublineares e retos; colorido geral mais avermelhado. Peru, Brasil (Amazonas) ........

P. costulatus (Bates, 1870)

7. Escapo curto e robusto, não atinge a borda anterior do protórax; manchas ebúrneas centrais com o mesmo comprimento; (antenas dos machos com abundante pilosidade sexual). Peru, Brasil (Pará, Maranhão, Rondônia, Mato Grosso), Bolívia P. triste (Blanchard, 1843)

7'. Escapo mais alongado, atinge a borda anterior do protórax; manchas ebúrneas centrais externas mais longas do que as centrais internas.

8. Élitros avermelhados com manchas centrais externas mais largas e contíguas; pernas avermelhadas; ápices dos mesofêmures com espinho curto na lado interno. Brasil (Pará, Maranhão) P. piruatinga Martins, 1997

8'. Élitros amarelados com as manchas centrais externas alongadas e separadas; pernas amareladas; ápices dos mesofêmures com abas apicais internas aguçadas ..................... 9

9. Manchas ebúrneas basais reduzidas e manchas centrais internas reduzidas, com menos da metade do comprimento das centrais externas; pubescência elitral densa. Colômbia (Cundinamarca, Meta)

P. martinezi Martins \& Galileo, 2002

9'. Manchas ebúrneas basais alongadas e mancha centrais internas alongadas, com mais da metade do comprimento das centrais externas; pubescência elitral esparsa. Bolívia (Santa Cruz, La Paz) ...... P. titinga Galileo \& Martins, 2004

\section{Pantomallus proletarius (Erichson, 1847)}

\section{Fig. 5}

Eburia proletaria Erichson, 1847: 149; Monné, 1993: 31 (cat.). Pantomallus proletarius; Martins, 1997a: 75; 1999: 216.

A fêmea agora examinada é o primeiro exemplar conhecido após a publicação da série-típica por ERICHISON (1847). Gilmour (1966) examinou essa série, designou lectótipo fêmea procedente do Peru e constatou que os paralectótipos são, na realidade, exemplares de $P$. morosus Audinet-Serville, 1835. A peculiaridade que chama a atenção são os élitros muito longos em relação ao comprimento do protórax (Fig. 5), aliás como já fora anotado por Gilmour.

Na chave publicada por Martins (1999), P. proletarius é discriminada junto com $P$. morosus. Martins julgava que ambas espécies tivessem a escultura dos élitros restrita à microescultura e sem pontos entremeados. Na verdade, em $P$. proletarius, os pontos são bem visíveis sob a pubescência.

Dimensões, fêmea. Comprimento total, 21,2; comprimento do protórax, 2,9; maior largura do protórax, 4,0; comprimento do élitro, 17,1; largura umeral, 5,5.

Material examinado. BolíviA, Santa Cruz: Achira (4-5 km N, 5400-5800 pés), fêmea, 17.XI.2003, Wappes, Moris \& Nearns leg. (ACMB); (Campo 5-5, 800 pés), macho, 9-11.X.2004, Wappes \& Morris leg. (ACMB).

\section{Pantomallus rugosus sp. nov. Fig. 6}

Etimologia. Latim, rugosus = enrugado; alusivo à escultura dos élitros.

Colorido geral castanho. Pubescência corporal amarelada; nos fêmures, acinzentada. Cada élitro com quatro manchas alongadas, ebúrneas, não contíguas: duas na base (a interna mais longa) e duas centrais (a interna mais curta). Lobos oculares superiores com sete fileiras de omatídios. Antenas atingem a ponta dos élitros na extremidade do antenômero VII. Escapo robusto, curto, atinge a margem anterior do protórax. Flagelômeros avermelhado-escuros com ápices pretos. Espinhos laterais do protórax evidentes. Élitros com pontos ásperos em toda a superfície; extremidades transversalmente truncadas e desarmadas. Profêmures fusiformes e largos. Abas apicais dos meso- e metafêmures não projetadas.

Dimensões, macho. Comprimento total, 22,4; comprimento do protórax, 3,9; maior largura do protórax, 6,1; comprimento do élitro, 16,1; largura umeral, 6,7; comprimento da manchas elitrais ebúrneas: basal interna, 1,3; basal externa, 0,8; central interna, 1,3; central externa, 2,2.

Material-tipo. Holótipo macho, Bolívia, Santa Cruz: Pampegrande (sic, Pampa Grande) (4-6 km S, 4600 pés), 1819.XI.2003, Wappes, Morris \& Nears leg. (USNM). Parátipo macho, Bolívia, Santa Cruz: Pampegrande (sic, Pampa Grande) (5 km S, oleoducto road), macho, 18-20.XI.2003, Morris, Nears \& Wappes leg. (CRML). 


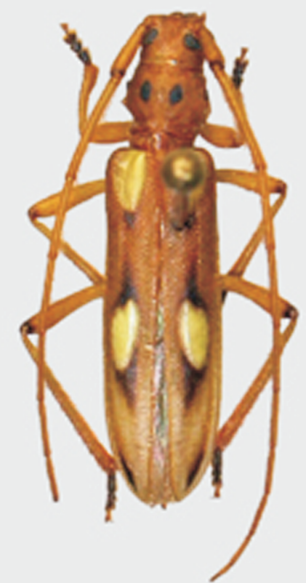

1
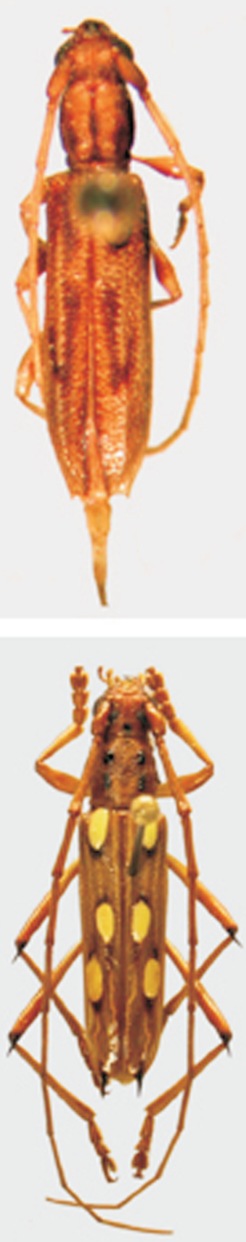

4

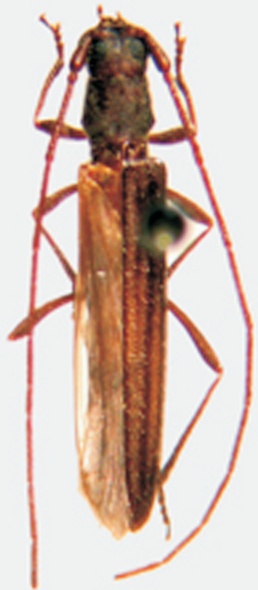

2
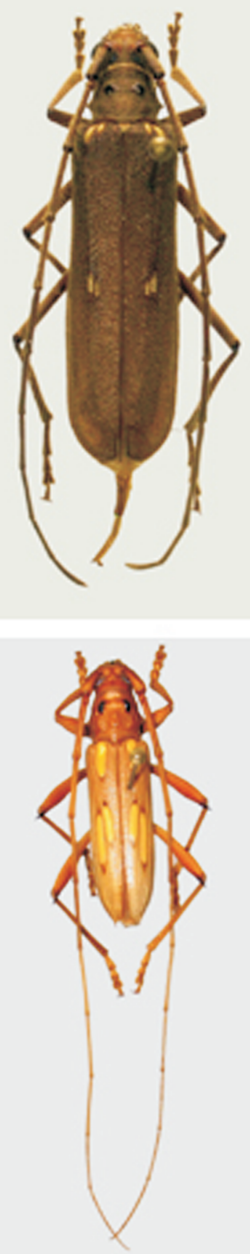

8
5

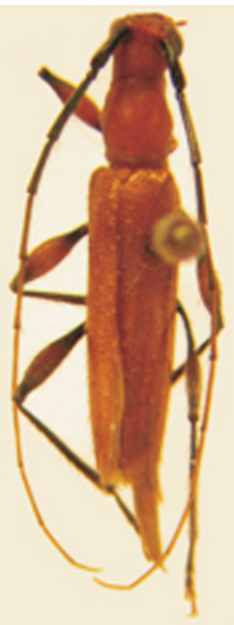

3

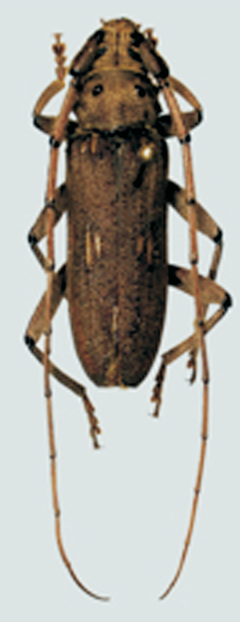

6

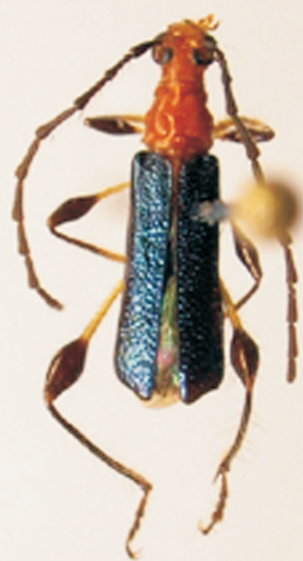

9

Figuras 1-9. (1) Paramartinsia quadrimaculata sp. nov., holótipo fêmea, 14,4 mm; (2) Sepaicutea costata sp. nov., holótipo fêmea, 11,1 mm; (3) Ectenesseca clavula sp. nov., holótipo fêmea, 10,1 mm; (4) Haruspex insulsus sp. nov., holótipo fêmea, 6,4 mm; (5) Pantomallus proletarius, 21,2 mm; (6) Pantomallus rugosus sp. nov., holótipo macho, 22,4 mm; (7) Eburodacrys apua sp. nov., holótipo macho, 17,4 mm; (8) Eburodacrys xirica sp. nov., holótipo macho, 17,0 mm; (9) Oxycoleus cyaneus sp. nov., holótipo macho, 5,4 mm. 
Discussão. Pantomallus rugosus sp. nov. é muito semelhante a Eburia sordida Burmeister, 1865, inclusive no aspecto da escultura dos élitros. Além das cavidades coxais anteriores angulosas nos lados, distingue-se pelas abas apicais das extremidades dos meso- e metafêmures não aguçadas e pelos ápices dos élitros sem espinho externo.

\section{Eburodacrys apua sp. nov.}

\section{Fig. 7}

Etimologia. Tupi, apúã = redondo; alusivo às manchas dos élitros.

Colorido geral alaranjado; cada élitro com três manchas ebúrneas elíptico-arredondadas: uma basal, uma no meio mais próxima da sutura e uma no início do terço apical; a borda anterior desta mancha inicia-se atrás da mancha central; faixas estreitas e amareladas, duas próximas da sutura da base ao meio e atrás da mancha central e apical, estão bem demarcadas e contrastantes com o fundo. Manchas e áreas pretas: mancha circular no vértice; seis manchas no protórax: duas sobre os tubérculos látero-anteriores e duas atrás deles; partes laterais do protórax com duas a cada dado: uma sobre o espinho lateral e uma entre esse espinho e a margem anterior; nos élitros: pequenas áreas atrás da mancha basal e adiante e atrás das outras manchas; espinhos dos ápices e área triangular à frente deles; espinhos apicais dos meso- e metafêmures.

Antenas dos machos atingem os ápices dos espinhos dos élitros na base do antenômero VIII. Escapo com pontos rasos e esparsos e sem sulco no lado dorsal da base. Pronoto transversalmente rugoso; as rugas irregulares; dois tubérculos ânterolaterais arredondados no topo. Espinhos laterais do protórax pequenos e aguçados. Pontos da metade basal dos élitros não ásperos. Espinhos dos ápices dos élitros e das pontas dos fêmures longos. Mesosterno sem tubérculo.

Dimensões, respectivamente macho/fêmea. Comprimento total, 15,5-16,9/17,4; comprimento do protórax, 2,6-3,0/2,9; maior largura do protórax, 2,6-3,1/3,0; comprimento do élitro, 11,1-11,8/12,5; largura umeral, 3,2-3,7/3,8.

Material-tipo. Holótipo macho, Bolívia, Santa Cruz: Buena Vista (4-6 km SSE, Hotel Flora \& Fauna), 27-29.X.2000, Wappes \& Morris leg. (MNKM). Parátipos: macho e fêmea, com os mesmos dados do holótipo (ACMB); ditto, macho,14-16.X.2000 (MZSP); macho, fêmea, 21-25.XI.2000, Morris, Nearns \& Wappes leg. (CRML); 2 machos, 17-19.X.2000, Wappes \& Morris leg. (MZSP, MCNZ); 3 machos, fêmea, 5-15.XI.2001, M. C. Tomas e B. K. Dozier leg., "tropical transition forest, blacklight trap" (FSCA); fêmea, 1-.XI.2002, J. E. Wappes leg. (ACMB); macho, 21-24.XI. 2003, Wappes, Morris \& Nearns leg. (ACMB); ("vicinity" Hotel Flora \& Fauna), macho, 14-16.X.2000, R. Morris leg. (CRML); 3 machos, 2 fêmeas, 17-20.X.2000, R. Morris leg. (1 macho MCNZ, 1 macho e 1 fêmea MZSP, restantes CRML); 2 machos, 2627.X.2000, R. Morris leg. (CRML); ("near" Hotel Flora \& Fauna. 350 m), macho, 16.XI.2003, Nearns, Morris \& Wappes leg. (CGN); macho, 21.XI.2003, Nearns, Morris \& Wappes leg. (CGN).
Discussão. Eburodacrys apua sp. nov. assemelha-se a $E$. alini Napp \& Martins, 1980, mas difere pelas antenas dos machos mais curtas; pela presença de quatro manchas pretas no pronoto; pela superfície pronotal rugosa; pelas manchas elitrais elípticas; pela presença de linhas longitudinais amareladas nos élitros. Em E. alini as antenas atingem o ápice dos espinhos elitrais pouco antes da ponta do antenômero VII; pronoto com duas manchas pretas e superfície com pontos, sem rugas; élitros com manchas ebúrneas alongadas e estreitas e praticamente sem linhas amareladas.

\section{Eburodacrys xirica sp. nov.}

\section{Fig. 8}

Etimologia. Tupi, xirica = enrugado; alusivo a escultura do pronoto.

Colorido geral alaranjado. Cada élitro com três manchas ebúrneas, elíptico-alongadas: uma na base, duas centrais com comprimentos subiguais, não contíguas, separadas entre si por distância pouco menor que a largura de uma mancha; a central externa inicia-se para atrás da central interna. Tegumento preto: duas manchas sobre os tubérculos ântero-laterais do pronoto; nos élitros, pequena área atrás da mancha ebúrnea basal e áreas anteriores e posteriores das manchas ebúrneas centrais; espinho dos ápices dos meso- e metafêmures. Espinhos laterais do protórax e dos ápices elitrais concolores.

Antenas atingem o ápice dos élitros partir da ponta do antenômero VII. Escapo com sulco no lado dorsal da base. Antenômero III profundamente sulcado. Espinhos do lados do protórax evidentes. Tubérculos ântero-laterais do pronoto longitudinais, divergentes e arredondados no topo; gibosidade centro-posterior quase lisa; restante da superfície pronotal finamente rugosa. Mesosterno sem tubérculo. Metade anterior dos élitros sem pontos ásperos. Espinhos dos ápices elitrais curtos, com menos da metade do comprimento dos espinhos femorais.

Variabilidade. Nas fêmeas, os tubérculos pronotais são mais projetados que nos machos. Num dos exemplares examinados, os élitros têm faixa preta estreita entre o ápice da mancha ebúrnea anterior e a mancha central interna. Linhas sinuosas, ebúrneas, da metade apical dos élitros mais marcadas nas fêmeas do que nos machos onde são pouco aparentes.

Dimensões, respectivamente macho/fêmea. Comprimento total, 16,4-17,0/14,8-19,1; comprimento do protórax, 3,0-3,4/ 2,8-3,6; maior largura do protórax, 3,6-3,9/3,1-4,3; comprimento do élitro, 11,7-12,1/9,7-14,0; largura umeral, 4,0-4,2/3,4-4,8.

Material-tipo. Holótipo macho, BoLíviA, Santa Cruz: Buena Vista (4-6 km SSE, Hotel Flora \& Fauna), 27-29.X.2000, Wappes \& Morris leg. (MNKM). Parátipos: BolíviA, Santa Cruz: Buena Vista, macho, 18-25.X.1992, E. Giesbert leg. (FSCA); (4-6 km SSE, Hotel Flora \& Fauna), fêmea, 17-19.X.2000, Wappes \& Morris leg. (MZSP); ditto, fêmea, 22-31.X.2000, Wappes \& Morris leg. (ACMB); fêmea, 23-26.X.2000, Wappes \& Morris leg. (ACMB); macho, 27-29.X.2000, Wappes \& Morris leg. (ACMB); 
macho, 14-19.X.2003, R. Clarke leg. (ACMB);(3,7 km SSE, Hotel Flora \& Fauna, 430 m), fêmea, 14-19.X.2000, M. C. Thomas leg. "transition forest, blacklight trap" (FSCA); fêmea, 1522.XI.2001, B. K. Dozier leg. "transition forest, blacklight trap" (MCNZ); ("vicinity" Hotel Flora \& Fauna), fêmea, 17-20.X.2000, R.Morris leg. (CRML); fêmea 22-26.X.2002, R.Morris leg. (CRML); Santa Cruz: Warmes (Hotel Rio Selva, 5 km ESE), macho, 2021.X.2000, Wappes \& Morris leg. (MZSP).

Discussão. Eburodacrys xirica sp. nov. assemelha-se a $E$. sanguinipes Gounelle, 1909 pelos espinhos protorácicos e elitrais concolores. Difere pelos tubérculos pronotais mais alongados e divergentes; pelo pronoto sem rugas desde os tubérculos até a margem anterior e com rugas muito débeis ou ausentes sobre a gibosidade central; pelas manchas ebúrneas dos élitros mais alongadas, a central interna é tão longa quanto dois terços da central externa. Em E. sanguinipes os tubérculos pronotais são arredondados e não divergentes; o pronoto é esculpido em toda a superfície; as manchas ebúrneas dos élitros são elípticas, as centrais são do mesmo tamanho.

O aspecto das manchas ebúrneas dos élitros lembra aquele de E. fortunata Lameere, 1884. Eburodacrys xirica difere pela ausência de mancha preta nos lados do protórax; pelo protórax mais estreito e sem rugas entre os tubérculos e a margem anterior.

\section{Oxycoleini}

\section{Oxycoleus cyaneus sp. nov.}

\section{Fig. 9}

Etimologia. Grego, kyanos = azul-escuro; alusivo à coloração dos élitros.

Cabeça, protórax, escutelo, esternos protorácicos e mesotorácicos, coxas posteriores, avermelhados. Antenas, clavas dos fêmures, metade basal das pró- e mesotíbias, metatíbias, metatarsos e urosternitos, pretos. Pedúnculo dos fêmures, metade apical das pró- e mesotíbias, amarelados. Élitros azuis metálicos, brilhantes. Flagelômeros III a V cilíndricos. Disco dos élitros sem carenas, deiscentes a partir da base, extremidades elitrais obliquamente truncadas e levemente entalhadas. Metatíbias com espinho tão longo quanto metade do metatarsômero I no ápice interno.

Dimensões, macho. Comprimento total, 5,4; comprimento do protórax, 1,6; maior largura do protórax (base), 1,1; comprimento do élitro, 3,7; largura umeral, 1,2.

Material-tipo. Holótipo macho, Bolívia, Cochabamba: Villa Tunari (1 km E), 8-12.X.1992, E. Giesbert leg. (FSCA).

Discussão. Oxycoleus cyaneus sp. nov. assemelha-se à $O$. laetus Julio, 1997, mas difere pelos esternos torácicos avermelhados; pelos élitros sem área basal avermelhada; pelas extremidades elitrais obliquamente truncadas e emarginadas; pelos pedúnculos dos fêmures amarelados e pelo espinho das metatíbias. Em O. laetus os esternos torácicos são pretos, os élitros tem o quinto basal avermelhado, as extremidades elitrais são arredondadas, os pedúnculos femorais são pretos e as metatíbias são inermes.

\section{AGRADECIMENTOS}

A James Wappes (ACMB) pelo envio do material para estudo; a Rafael Santos de Araujo (MCNZ) pela execução das fotografias.

\section{REFERÊNCIAS BIBLIOGRÁFICAS}

ERICHSON, W.F. 1847. Conspectus insectorum coleopterorum quae in Republica Peruana observata sunt. Archiv für Naturgeschichte, Berlin, 13: 67-185.

Gilmour, E. F. 1966. The Erichson species of Eburia and Eburodacrys (Col., Cerambycidae, Cerambycinae, Hesperophanini). Mittheilungen aus den Zoologischen Museum in Berlin, 42(2): 163-176.

Martins, U.R. 1976. Sistemática e evolução da tribo Piezocerini (Coleoptera, Cerambycidae). Arquivos de Zoologia, São Paulo, 27 (3-4): 165-370.

MARTINs, U.R. 1997a. Contribuições para uma revisão das espécies sul-americanas da Tribo Eburiini. Revista Brasileira de Entomologia, São Paulo, 41 (1): 57-83.

Martins, U.R. 1997b. Cerambycidae sul-americanos (Coleoptera). São Paulo, Sociedade Brasileira de Entomologia, v. 1, $217 p$.

Martins, U.R. 1998. Cerambycidae sul-americanos (Coleoptera). São Paulo, Sociedade Brasileira de Entomologia, vol. 2, $195 \mathrm{p}$.

Martins, U.R. 1999. Cerambycidae sul-americanos (Coleoptera). São Paulo, Sociedade Brasileira de Entomologia, vol. 3, 418p.

Monné, M.A. 1993. Catalogue of the Cerambycidae (Coleoptera) of the Western Hemisphere. Part II. Subfamily Cerambycinae: Tribes Hesperophanini and Eburiini. São Paulo, Sociedade Brasileira de Entomologia, 77 p.

NAPP, D.S. \& U.R. MARTINs. 1982. Subsídios para revisão taxonômica da tribo Achrysonini (Coleoptera, Cerambycidae) nas Américas. Papéis Avulsos de Zoologia, São Paulo, 34 (28): 349-401.

Recebido em 06.XII.2004; aceito em 22.VIII.2005. 